\title{
Marital Rape
}

\section{Nasreen Alsam Shah, Shagufta Nasreen \\ \&}

\author{
Aliyah Ali \\ Women's Studies \\ University of Karachi
}

\begin{abstract}
Rape is a form of violence which exists from the ancient times in history. But it has been used to express power over women by men. Although we believe in Islam, which give us a charter of human rights long before it was recognized by the world, it has been interpreted to support some ideas which are misquoted or not explained with their contexts. Similar condition is in the case of marital rape which is an issue not acknowledged in Pakistan. This issue was initially raised by women rights activists. The issue is hushed up because it is considered that once married women give up her right on her body. Since forced sexual relations between a husband and wife are not legally considered cases of "rape" the question arises whether or not a wife herself views the incident as a "rape". There are two important issues, which must be researched in the case of marital rape. The first area is victim offender relations and the second considers the element of power
\end{abstract}

$$
\begin{aligned}
& \text { تلخيص المقال }
\end{aligned}
$$

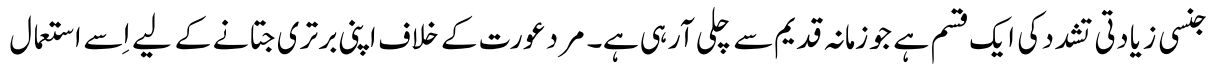

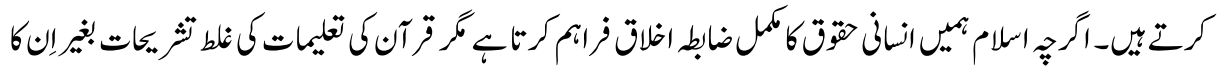

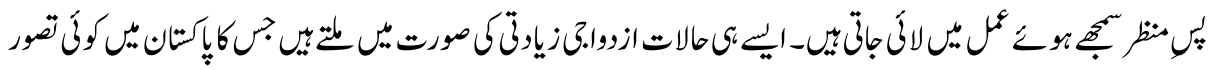

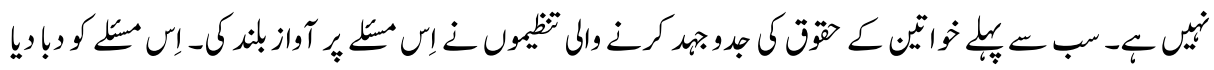

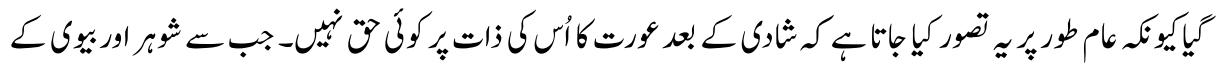

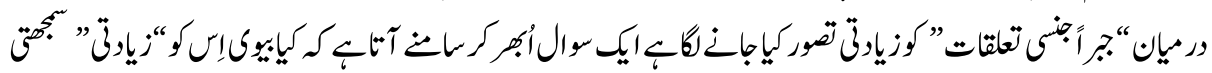

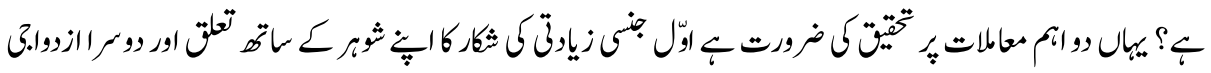

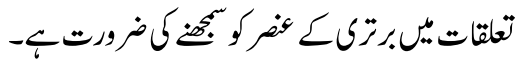

Rape is a form of violence which exists from the ancient times in history. But it has been used to express power over women by men. When we see news or hear an incident of rape, it leaves a shocking impact on us. The trauma, fear, and pain associated with this word, could actually be felt by the survivor who has experienced it and by anyone who come across with it either by reading, research or listening it. It affects the survivor's physical, social, psychological life. There are social, legal and cultural issues regarding rape. One problem associated with it is that often the survivor is held responsible for it. Although we believe in Islam, which give us a charter of human rights long before it was 
recognized by the world, it has been interpreted to support some ideas which are misquoted or not explained with their contexts. Similar condition is in the case of marital rape which is an issue not acknowledged in Pakistan. This issue was initially raised by women rights activists. They were blamed of propaganda for the "western ideas". The expression of this unacceptability was publicized when in 1999 a film "Inteha"(i) on this issue was highly criticized and it was banned but later the director took stay order on the court decision. The issue is hushed up because it is considered that once married woman give up her right on her body, often an Hadith is quoted (ii), First of all we will investigate does marital rape exist? Gelles quote three definitions as being defined conceptually as "any sexual intimacy forced on one person by another". Another as "culturally disvalued use of coercion by a male to achieve the submission of a female to sexual intercourse" third is the dictionary definition that "sexual intercourse with woman by a man without her consent and chiefly by force or deception". Thus he concludes that by definition any woman can theoretically be raped by any man (Gelles, 1980). ${ }^{1}$ But it depends on the texture of the criminal justice system in which how they are defining rape. Niaz explains that sexual violence within the family includes rape, sodomy and incest. The Zina ordinance which deals with rape, defines rape (zina-bil-jabr) as sexual intercourse with a woman or a man as the case may be, to whom he or she is not validly married," this definition of rape categorically rules out the possibility or recognizing marital rape as an offence. However since sodomy is considered carnal intercourse against the order of nature, a man can be charged with committing sodomy with his wife although he can not be charged with raping her (Niaz, 2000). ${ }^{2}$ In Pakistan NGO Review, it was identified that various forms of violence to which women are subjected in society were discussed in 1995 Pakistan National Report for Beijing (Net Rep). It emphasized that both overt and converts forms of violence against women are part of a continuum underpinning all spheres of private and public life. But issues inter-linked with violence such as STD's, RTI's and HIV/AIDS as a direct consequence of sexual violence against women, external and marital rape, trafficking, etc. were not clearly addressed in the report (Shirkat Gah, 2007). ${ }^{3}$ In August 2009 National Assembly has passed a bill on domestic violence(iii). It uses a term sexual abuse but spousal rape or marital rape is not defined. According to the bill, domestic violence includes — but is not limited to - 'all intentional acts of gender-based or other physical or psychological abuse committed by an accused against women, children or other vulnerable persons, with whom the accused person is or has been in a domestic relationship'. Some of such acts could be 'assault' as defined in the Pakistan Penal Code, use of criminal force, criminal intimidation, economic abuse, entry into an aggrieved person's residence without his or her consent, harassment, 'mischief' against property, physical abuse, stalking, sexual abuse, verbal and emotional abuse, insults or ridicule, 'willful or negligent abandonment of the aggrieved person', wrongful confinement and 'other repressive or abusive behavior ... where such a conduct harms or may cause imminent danger or harm to the safety, health or well-being of the aggrieved person' (Asghar, 2009). 
The global situation is not very different and the problem exists every where. When it comes to defining, prosecuting, and penalizing such offenses, the laws vary widely. According to the National Clearinghouse for Marital and Data Rape, a group based in California, there remains six states in which marital rape is not a crime if the couple is living together: Missouri, New Mexico, North Carolina, North Dakota, Oklahoma, and South Carolina. The assumption of the legislative bodies in these states is that when a woman gets married, she has conferred "conjugal rights" on her husband and given up her right to say "no" (Christmas, 1993). ${ }^{4}$ For many years, police were reluctant to investigate and prosecute marital rape. In landmark case from 1978, Greta Ride out of Oregon filed charges against her husband for nonconsensual sex, bringing marital rape to national attention. Approximately 13 percent of married women have been raped by their husbands (Russel, 1990). In most cases, the husbands used force (84 percent or the threat of force ( 9 percent). The rape was an isolated incident for 31 percent of the victims. Another 31 percent reported being raped more than 20 times, and the rest fell somewhere in the middle (Blonna, 2005). ${ }^{5}$

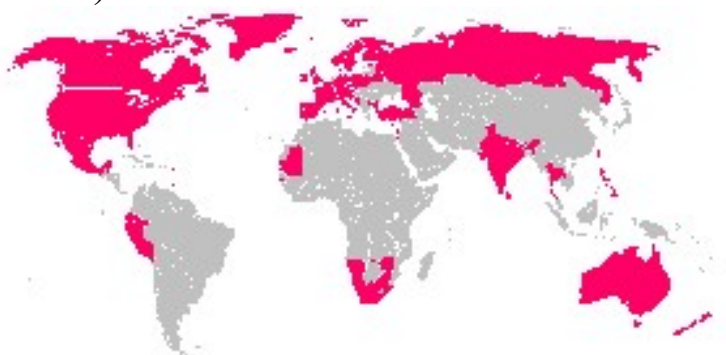

Marital rape has specifically been criminalized. It should be noted that in the un highlighted countries, a rape within marriage may or may not be prosecutable under normal rape laws, but no specific crime of marital rape exists. It should not be construed that marital rape is permissible in the UN highlighted countries Sources: (Unicef, 1997) ${ }^{6}$ and (UNIFEM, 2003).

Since forced sexual relations between a husband and wife are not legally considered cases of "rape" the question arises whether or not a wife herself views the incident as a "rape". Thus, if the victim herself is unlikely to view the behavior as "rape", how can we discuss the phenomenon "marital rape"? Women who have been beaten severely by their husbands often state that they deserved to be hit, that they "needed to be hit", or that "husbands are supposed to hit their wives". The fact that women are socialized to believe and are frequently denied proper legal rights that violence between spouses is expected and normative, does not diminish the fact that women are often injured by their husbands in trying to redress these acts (Blonna \& Levitan, 2005). ${ }^{7}$

There are two important issues, which must be researched in the case of marital rape. The first area is victim offender relations and the second considers the element of power (Gelles, 1980). ${ }^{8}$ Usually it is considered that women are typically raped in alone places by strangers. The research carried out on patterns of rape indicates that this is not the 
reality. In 1975, the results of an American study on many rape situations were published. Russell was so appalled by her findings on rape in marriage that she decided to conduct a research project on this area alone. From the 930 interviews conducted with women from a cross section of race and class, Russell concluded that rape in marriage was the most common yet most neglected area of sexual violence (Russel, 1990).

In 1994, Patricia Easteal, then the Senior Criminologist at the Australian Institute of Criminology, published the results of survey on sexual assault in many settings. The respondents were survivors of numerous forms of sexual assault. Of these, $10.4 \%$ had been raped by husbands or de facto spouses, with a further 2.3 per cent raped by estranged husbands/de factos. In the UK, statistics disseminated by the Rape Crisis Federation yield the information that the most common rapists are current and exhusbands or partners (Myhill \& Allen, Rape and Sexual Assault of Women: Findings from the British Crime Survey) (Gracia-Moremo, 2005). Commonly it is perceived that women are raped by men other than their partners but data have revealed that, over $75 \%$ of the women who have been physically or sexually abused, report abuse by their partner. About $10-20 \%$ of the women surveyed in 5 out of 10 countries believed that a woman does not have a right to refuse sex to her husband under any circumstances (Ali). In a study related to domestic violence and marital rape, it was found to be associated with depression, as it may lead to a feeling of degradation, negative self image and cause shame, guilt and fear which are known predisposing factors for depression. Some women with history of marital rape report flash-backs, sexual dysfunction, and emotional pain for years after the violence. Marital rape may be even more depressing then rape by a stranger as victims of marital rape may experience additional trauma of betrayal, but these assumptions need to be studied and explored further. There may be some under reporting of marital rape by wives in our study because it is so common, that it may be considered as a norm rather than an act of violence. In a study in Pakistan, $77 \%$ of men admitted to ever engaging in a non-consensual sex with their wives, which suggests that there is no shame or stigma attributed to the husband. The fact that in our study abuse by spouse was not significant in the multivariable model could be due to significant overlapping between emotional, verbal and physical abuse and sexual violence or marital rape which is also a form of physical violence. Studies in the past have shown that marital rape is also associated with various gynecological diseases which may lead to lower frequency of sexual activity. We were unable to establish a temporal relationship between low sexual activity and depression, because our study was not designed to examine this question, and depression itself leads to decreased sexual desire (Ali). Pakistan is a signatory of the 1993 Declaration on the Elimination of Violence Against Women explicitly recognizes marital rape as a form of violence against women under article 2, similarly the committee of the Convention on the Elimination of all Forms of Discrimination Against Women (CEDAW), to which Pakistan is a state party, has recognized marital rape as a form of violence against women under General Recommendation on 12 and 24 but remain unsuccessful to make specific laws on this sensitive issue which also indicates the patriarchal thinking of the ruling class (Kiffe). 
The second theme is about power relationships. Brown miller explains that the basis of patriarchy lay in biology, men physically have the capacity to rape and it is this power that they use to control and intimidate women. If rape is viewed as an act of violence and of power we could deduce that men who have few social and psychological resources are likely to use an act such as marital rape to intimidate, coerce and dominate their wives. Since rape can be a degrading experience some husbands may use this act to humiliate their wives and thus gain degree of power and control over their spouses (Gelles, 1980). ${ }^{9}$ Majority of women who suffered from marital rape do not really know that they are victims, because the rapist is a close acquaintance. Women usually think that their feelings of fear, revulsion, depression and anger are wrong. The survivor is likely to deal with betrayal, broken trust, feelings of grief and loss, loss of self esteem, feel worthless, and all these factors affect the personality negatively especially when she does not find any support from the family (IWRAW Asia Pacific, 2008).

\section{Issues}

Researches on violence usually do not include marital rape because of consideration that it is not violence but right of male spouses. Another difficulty is that often survivors do not want to discuss it with anyone thinking that it is a private matter. Operational definitions of rape include physical abuse or force violence. Usually the focus of research is on aftermath or results but not attacks.

"In case study of Nooreen her husband was very aggressive and forced to do sex with out her will and if denied he used to beat and assault her with metallic belts and forced her to put off all her clothes. This behavior of her husband affected her psychologically and under psychological treatment".

There is also a thought that pornography is increasing the rape. Should laws be changed if all wives could take their husbands to court for forcing them into having sexual intercourse, this might flood the court with intra-family litigations. The already burdened criminal justice system probably couldn't handle the large number of cases. Another case study indicated the requirement for change in laws.

"Shaheen Bano told that not only her husband forced her for sexual intercourse but on her denial he used to assaulted her and often beated her. Once on her refusal he attacked her with knife".

Any legal change would also have to be accompanied by social, attitudinal and moral changes. The thought and behaviors of the entire society and concept of public and private life need to be changed and revised. Gender inequalities and imbalances also affect the private lives in a negative manner. 
"Arifa's husband forced her to do intercourse and enjoyed to harm her in such a way that she was started shouting. He also did anal sex with her. Because of his continuous abuses she faced DNC two times".

\section{Methodology}

Three respondents were selected for the research. It was promised to hide their names and where about. The respondents were living in the shelter home Karachi. The interviews were taken through unstructured questionnaire.

\section{Findings}

The study shows that the survivors belonged to the middle and lower middle class families. They were forced in to marriage by their families especially from their mothers. Their mothers were very strict and fathers were soft natured. They got divorced because of the brutal behavior of their male spouses. During discussion it was revealed that the main cause of their divorce was their husband's abuse during intercourse and their beating on their denial. The husbands behaved that it was their right to humiliate them. This behavior affected them both mentally and physically. One of the victim disclosed that she could not sleep at night or started screaming during sleep. The victims also stated that they felt depression, irritation and became aggressive. They were under psychological treatment but still face serious mental pressure. They were not living with their parents who showed the attitude of their siblings as already stated that their mothers were very strict and did not like their acts.

\section{Case History: 1}

Noureen is a 35 years young lady. She has 3 sisters and had a brother (Late). She belong to a middle family. In her family mother was the dominant character while father was so friendly. She has done BA on father's support and mother was not willing. She said I had no attachment with mother due to lack of emotional support from her side. Her father is patient of Amnesia and has a history of psychological pier treatment.

At her teen age she got involved in a by living next to her street, who was also his father's friend's son.

They both were interested in each other. Her father and his friend had a clash between them on some dispute. Due to that when boy sent marriage proposal to her family through his parents. Her mother refused the proposal without informing her.

When her mother came to know that she is also interested in that boy she urgently arranged her marriage with a relative. The person with whom she got married liked her 
but many physic problems. Her husband was more attached to his mother and used to share every thing with his mother even private life relationships.

He used to take care of her but at the same time he was very aggressive in his sexual relationship. If he had urge of sex no matter she was agreed or not he just go for it and of denied he used to beat $n$ assault her with metallic belt and forced her to put of her all cloths once he did that he went out of the bedroom and after few hours he used to come back and ask for the pardon.

She forgives him many times but at last when this violence became unbearable for her she decided to left him. Finally she came back to her parent's home and got divorce from him. Due to such incidents she suffered from many psychological problems. Her mother was very angry on her for this act.

Due to this sort of behavior from her mother she left her home as well and now she is serving as a house mother in an Orphan's Village/ Organization.

\section{Case Anaylsis}

Noureen seems to be a very simple and kindhearted woman. Although she is performing at her best but she still has some psychological problems. She gets easily aggressive, irritated, she start crying on very miner things and at times feels difficulty to coupe with the situations. As according to her "I used to coupe up with such situations easily before those miserable incidents"

(She is more prone to depression and is under psychological treatment.)

\section{Case History: 2}

Arifa is about is about the age of $30+$. She belongs to a well educated upper middle class family. She has 5 sisters and 2 brothers. All the brothers and sisters are married and well established. Her father used to remain out of city due to his job and mother was very strict about the rules and regulations.

In her family always "arrange marriages" were take place. The problem with the person she got married was that he was not all attached with his family and his family had forced him for this marriage. After sometime of marriage her husband separated his room from her. She was strictly restricted to no go anywhere and remain at home all the time.

When he had urge of sex he used to catch her (no matter in what position/ condition she is) he forcibly do it with her. During this intercourse he enjoyed to harm her in such a way so that she could shout, he pinched her with his nails. And also he goes for anal sex. 
She got pregnant for three time (because of these marital rapes). Very fast time when she got pregnant beaten her a lot she had a DNC. Second time due to his assault she had a premature baby boy who died on the $2^{\text {nd }}$ day of birth. And when she was at the hospital no single person was with her in hospital.

Third time when she got pregnant, he as usual beaten her lot but she did not left happened anything to her baby. That was actually twin baby girls. Her husband's behavior to her daughters remained good but not with her wife. He used to torture her so that many leave him by herself of run away or commit suicide. Finally she left the home and went to a shelter home. She got divorce from her husband. She had so many psychological problems and still have some of them.

Now she is serving as a house mother in an Orphan's Village/ Organization.

\section{Case Analysis}

Her sleeping pattern is not still good, she don't sleep much of the time in night. She is not social at all. She is under psychological treatment and takes psychiatric medicines.

She seems to be much confused and anxious.

\section{Case History: 3}

Shaheen Bano is a 30 years old woman belongs to Hazara. Shaheen Bano belongs to a normal middle class family. She had 3 sisters, now died during their pregnancies. Her father had his own farms their home environment was good. Mother got married for second time, her father arranged her marriage ta a boy in the same village. Her husband was nice and had his own farms but she was suffering from cancer thus died very soon. She has a daughter from his late husband. Then she came to her mother and started working in garment's factory.

Her mother got her marriage second time with a men in neighbor but this person but this person was very cruel, He used to beat her, spy over her, was not maintaining her at all. Besides this he used to take off her earning as well. He used to maintain an other Woman/Lady, which was according to him his said sister. But she believes they were having an affair with each other. She has 2 children from him a son and a daughter respectively. Other than job timings he used to lock her at home. And in the night used to forced her for sexual intercourse and on her denial he assault her, and beat her. After this particular incident she usually felt very bad, and sometimes become ill. Once upon when she denied for such way intercourse he attacked over her with Knife. For the second time when he and that other lady assaulted her and she came also came to know that he is willing to sale her (late husband's) daughter she was shocked and frightened enough that she felt the home along with her children. Now she is in a shelter home and want divorce from her husband. 


\section{Case Analysis}

She always feel the pain in her whole body, and this is the same pain she used to fell after that marital rapes. She often has a High BP. Still she don't have sound sleep at night and feel tense all the time.

\section{Key Notes}

(i) "Inteha" directed by Samina Pirzada, an actress, director and women rights activist directed this film. She was criticized for raising an issue which is not accepted in an Islamic society. The film was also criticized for its open and bold scenes.

(ii) Sayyiduna Abu Huraira [ Allah be pleased with him ] narrates that the Messenger of Allah [ Allah bless him \& give him peace ] said: If a man calls his wife to his bed [i.e. to have sexual relations ]; and she refuses and causes him to sleep the night in anger, the angels will curse her till morning Sahih Bukhari [ Bad' al-khalq 7 ] ; Abu Dawud [Nikah 41 ]

(iii) The first breach of a protection order will be punishable with imprisonment of up to one year, but not less than six months, and a minimum fine of Rs100, 000, which will be paid to the aggrieved person. But a violation for the second or third time, or more, will be punishable with up to two years' imprisonment and a fine of not less than 200,000 payable to the aggrieved person.

\section{End Notes}

${ }^{1}$ Gelles, R.J. Power (1980) "Sex and Violence: The Case of Marital Rape" In James M. Henslin(Edt.) (1980) Marriage and Family in a Changing Society, New York, The Free Press, p. 390.

2 Niaz, Uniaza (2000) “Women's Mental Health" In Pakistan Psychiatric Society, Karachi p. 194.

3 Shirkat Gah (2007) "Talibanisation and Poor Governance: Undermining CEDAW in, Pakistan" In Pakistan NGO Review: Beijing+5, Lahore, Shirkat Gah Women Resource Centre, p. 47.

${ }^{4}$ Christmas, June Jackson (5th Edi) (1993) Every Woman's Health: The Complete Guide to Body and Mind, USA, Doubleday Book \& Music Clubs, p. 423.

5 Blonna, Richard \& Levitan, Jean (2005) Healthy Sexuality, USA, Peter Marshall, pp.526-527.

${ }^{6}$ UNICEF (1997) The Progress of Nations, p.48. 
7 op. cit.,

${ }^{8}$ Gelles, op. cit., (1980), p.393.

${ }^{9}$ Ibid.,

\section{References}

Ali, F. A. (et. al) Association of various reproductive rights, domestic violence and marital rape with depression among Pakistani women, retrieved on Feb 10th, 2010, http://www.biomedcentral.com/1471-244X/9/77

Asghar, Raja (Wed. 05, Aug. 2009) NA bill outlaws domestic violence, Daily Dawn.

García-Moreno, C, Jansen, H.A.F.M, Ellsberg, M, Heise L, Watts, C. (2005) WHO Multicountry Study on Women's Health and Domestic Violence against Women Initial results on prevalence, health outcomes and women's responses, Geneva, World Health Organization.

IWRAW Asia Pacific (2008) "Statement delivered by Lisa Pusey on behalf of International Women's Rights Action Watch Asia Pacific" In Human Rights Council. Consideration of Universal Periodic Review, Retrieved on Feb $18^{\text {th }}$ 2010, www.upr-info.org/IMG/pdf/IWRAW_Pakistan_Plenary.pdf

Kiffe, Barb Maritial Rape Retrived on Feb $18^{\text {th }}$, 2010, www.wcsap.org/advocacy/PDF/MaritalRapeDekota.pdf-

Russell, Diana E.H. (1990) Rape in Marriage, USA, Macmillan Publishing Company.

UNIFEM (United Nations Development Fund for Women) (2003) not a minute more: Ending Violence Against Women, 2003.

Prof. Dr. Nasreen Aslam Shah is Director at Centre of Excellence for Women's Studies, University of Karachi.

Shagufta Nasreen is Lecturer at Centre of Excellence for Women's Studies, University of Karachi.

Aliyah Ali is Lecturer at Centre of Excellence for Women's Studies, University of Karachi. 
Zar Bano Student of BS $3^{\text {rd }}$ Year, Centre of Excellence for Women's Studies has taken the case studies we are really obliged for her cooperation. 